Assessment of Farm Accountancy Data Network System in Croatia

Procjena sustava poljoprivrednih knjigovodstvenih podataka (FADN) u Hrvatskoj

Juračak, J., Očić, V.

Poljoprivreda/Agriculture

ISSN: 1848-8080 (Online)

ISSN: 1330-7142 (Print)

https://doi.org/10.18047/poljo.27.2.12

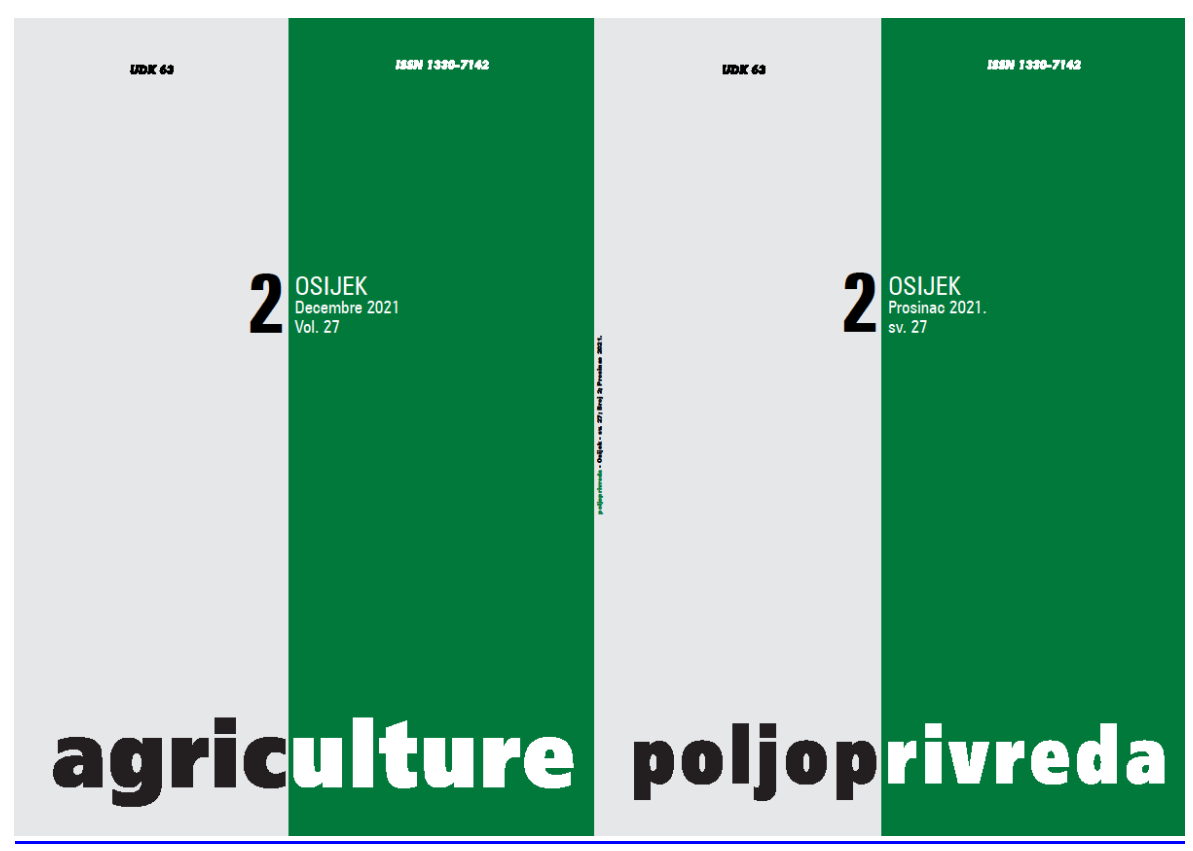

Fakultet agrobiotehničkih znanosti Osijek, Poljoprivredni institut Osijek

Faculty of Agrobiotechnical Sciences Osijek, Agricultural Institute Osijek 
ISSN 1330-7142

$U D K=631.162(497.5)$

https://doi.org/10.18047/poljo.27.2.12

\section{ASSESSMENT OF FARM ACCOUNTANCY DATA NETWORK SYSTEM IN CROATIA}

Juračak, J., Očić, V.

Scientific review
Pregledni znanstveni članak

SUMMARY

Croatia is the newest member of the EU Farm Accountancy Data Network (FADN). So far, no comprehensive evaluation of the national FADN system has been conducted, and this study based on a survey of staff involved and a desktop analysis was conducted to fill this gap. The three main elements of the Croatian FADN system are the National FADN Committee, the Ministry of Agriculture as Liaison Agency (LA) and the Croatian Bureau for statistics. All FADN survey activities are carried out by LA and the main burden of data collection lies with the data collectors and the farms. The system operates in accordance with relevant EU legislation and currently its main objective appears to be the fulfilment of its obligations to the FADN network. Other benefits like analysis of CAP measures etc. are not yet exploited. The main challenges are further development of quality assurance systems, the motivation of staff and farms to participate, the increased use of FADN data, and the expected changes in transformation of the FADN into the sustainability data network (FSDN). Croatia will successfully meet these challenges if it strengthens its capacity for FADN research and data analysis and establishes an effective quality assurance system.

Keywords: Croatia, FADN, farm accountancy, quality assessment, FSDN

\section{INTRODUCTION}

The concept of Farm Accountancy Data Network (FADN) was launched in 1965 by Council Regulation $79 / 1965$, which provide the original legal basis for the organization of the system. Over time, the regulation was amended several times and finally replaced by the current Council Regulation (EC) 1217/2009 of 30 November 2009 as a legal basis of the FADN. The key aim of the of the FADN network is the collection of data on resources, production, costs and incomes of agricultural holdings on an annual basis. This is the only source of microeconomic data that is methodologically harmonized and comparable among all members of the European Union (EU) and some non-member countries e.g., Norway, Switzerland, Serbia, Kosovo. The main objective of the FADN survey is to obtain representative data for the national and for the population of agricultural holdings in the EU. It is recommended that the data represent $90 \%$ or more of (1) the utilized agricultural area, (2) the total livestock units and (3) the total agricultural output at a statistically reliable level current (Council
Regulation (EC) 1217/2009). Consequently, the FADN populations do not have to include all agricultural holdings but are sized to meet the above recommendation. The key criterion or lower threshold of the population is the economic size, measured by the value of the standard output (SO) of the farm. SO is the average monetary value of the agricultural output at farm-gate price. Economic size of a holding is the value of its total SO (EC, 2009). FADN data, as well as the analyzes based on them, have become an indispensable tool and the main basis for the evidence-based policies of the EU Common Agricultural Policy (CAP) and national agricultural policies. They are widely used to assess and plan the impact of policies on the agricultural sector. FADN survey results are published as statistics for both the EU and the Member States. Today, Member States need to achieve the Green Deal objectives and targets. Because of that Farm Accountancy Data Network need to convert into the Farm Sustainability Data Network (FSDN), to

Asst. Prof. Josip Juračak, Asst. Prof. Vesna Očić (vocic@agr.hr) University of Zagreb, Faculty of Agriculture, Svetošimunska cesta 25, 10000 Zagreb, Croatia 
provide feedback and guidance to farmers and link their experience to the European Innovation Partnership and research projects $(E C, 2020)$.

The beginnings of the establishment of the FADN system in Croatia date back to 2008, when the first farm-level income survey was conducted on a representative sample. The first FADN survey was conducted in 2013 as a pilot project, and in the same year Croatia became a member of the EU (Agricultural Advisory Service, 2013). Next year (2014), the FADN survey was officially conducted for the first time on the whole national sample and the collected data were verified by the RICA (i.e., FADN) office at European Commission. The Croatian FADN sample consists of 1,285 farms on average (economic treshold: more than EUR 4,000 SO). Participation of farms in the survey is voluntary according to Council Regulation (EC) No. 1217/2009.

Bradley \& Hill (2015) examined the costs and good practices for collecting FADN data in EU Member States. They found wide variation in the organization of national farm survey. In 14 countries, research institutions or extension services have the status of responsible bodies (i.e., Liaison Agencies, LA), while in 12 countries LA are located in ministries. In 2 cases, the LA is the government statistical office. LA may carry out data collection itself or outsource it. States where extension agencies combine data collection with the provision of extension services have the highest public cost per farm. The benefits of FADN and national farm account surveys depend on the impact on user decisions. If the data are not used or ignored, there is no benefit (Hill et al., 2016a). In the same paper they provide several examples of best practices in collecting FADN data. Some of these include the usage of existing administrative data sources to reduce collection costs, implementation of validation procedures at multiple points, and implementation of systems that learn from past experiences. To avoid testing legal constraints, access to administrative data must be through consent.

In many countries, especially the more experienced FADN countries e.g., Netherlands, Poland, Hungary, the standard farm report for the FADN has been extended to allow analysis beyond the collection of the requested data. Expanding the FADN dataset to include sustainability data would increase costs by about $40 \%$. The increase in costs due to the extension of the FADN survey will vary considerably across countries (Vrolijk \& Poppe, 2019). Based on a study conducted in Italy, Longhitano et al. (2011) find that the FADN already contains certain environmental and social data. However, additional information is needed to gain a comprehensive insight into the environmental and social aspects of farms in the context of sustainable development. The extension of the standard report depends on the needs for analysis and institutional capacity in a country (Diazabakana et al., 2014; Hill et al, 2016b). This requires a trade-off between the financial cost and burden on farmers on the one hand and the value of the data collected on the other. A complicating factor is that policy makers are very concerned with the burden on farmers in their country, while much of the added value of data for policy making is recognised at the European level.

Apart from the authors already mentioned (Vrolijk \& Poppe, 2019; Hill \& Bradley, 2016), who made comparisons of FADN systems between different countries from the point of view of organization and costs, there is very little research on the topic of evaluating the functioning of FADN systems. The approach to FADN system assessment may vary. It is possible to evaluate the system from the point of view of benefits to users. On the other hand, the FADN can be considered as a statistical survey, which means that the quality criteria of the statistical system could also be applied. Based on the latter approach, an evaluation of the FADN system was conducted in Slovenia, which resulted in 6 key guidelines, as follows: (1) the need for a national consensus on the main users of FADN data for Slovenia and their data needs, (2) institutional reorganization and greater specialization of staff working on the FADN, (3) digitization of the system to reduce costs and workload, (4) strengthening and increasing the quality of dissemination of FADN results and education (simplify and personalize FADN feedback for farms), (5) strenghthening the agricultural extension service as a direct link to sample farms, and (6) shift the burden of data accuracy and reliability from farmers to FADN system (Kožar, 2016).

So far, no analysis has been conducted to comprehensively evaluate the functioning of the FADN system in Croatia, although the FADN survey has been conducted seven times (2014-2020), with verified data available for five accounting years. We assessed of the state of the system considering its efficiency and effectiveness in relation to the given purpose and objectives. For quality assessment it is necessary to get the most objective picture of the state of individual elements of the system, taking into account clearly defined determinants of quality. Therefore, this paper presents the results of the first comprehensive review and evaluation of the FADN system in Croatia from the perspective of organization, quality, and effectiveness of implementation.

\section{MATERIAL AND METHODS}

In conducting this research and making of our evaluations, we have been guided primarily by the European Statistics Code of Practice (ESS, 2017), since the FADN survey has many characteristics of a statistical survey. To gain insight into all elements of the system, a study was conducted combining a desktop analysis and a survey. The desktop analysis examined laws and regulations, written rules and procedures, and online materials that may affect the quality of the FADN system. In addition to the national ones, the relevant materials at the level of the FADN system in the EU were also examined. 
Another part of the process to gather information on the state and functioning of the FADN system in Croatia was a survey of the staff involved. Information about the system was collected using the following tools: (1) online survey of members of the National FADN Committee ( $N=9$ ), (2) semi-structured interviews with staff of the two administrations of the Ministry of Agriculture of the Republic of Croatia who participates in the FADN survey $(\mathrm{N}=8)$, (3) semistructured interviews with staff of the Croatian Bureau of Statistics who participates in the FADN survey ( $\mathrm{N}=$ 3 ), and (4) data collectors survey using a self-completion questionnaire $(\mathrm{N}=52)$. A survey of data collectors was conducted using the application. Respondents were familiarized with the purpose and content of the questionnaire before conducting the survey. The survey was conducted in groups, with the presence of the researcher in case additional clarification was needed.

\section{RESULTS AND DISCUSSION}

\section{Institutional framework and structure of the FADN system}

The institutional framework for the FADN system in Croatia consists of the National FADN Committee (NFC) and two institutions: the Ministry of Agriculture and the Croatian Bureau for Statistics (CBS). NFC is the supervisory body for the implementation of FADN research. The chairman of the NFC comes from among the representatives of LA (Ministry of Agriculture). The current structure of the FADN system complies with the EU requirements and regulations, which was confirmed by the short-term mission of the EC in 2019, which gave a positive report on the state of the system.

The functioning of the FADN system in Croatia depends almost entirely on the human and material resources of the Ministry of Agriculture. The Ministry of Agriculture has the role of Liaison Agency (LA) since 2019. It fulfills its LA obligations through the "Unit of Agricultural Accounting Data System (FADN)", which works within the "Department of Agricultural Information Systems" in the "Sector of Agricultural Policy". About 60 persons are involved in the implementation of the FADN survey, of which only two are employed by the CBS outside the Ministry of Agriculture. Only one of these 60 persons is employed full-time with the FADN system at the time of this evaluation. Other staff work for FADN occasionally which work makes part of their full-time work at the ministry. According to their own estimates, individuals spend $5 \%$ to $50 \%$ of their total work time working on the FADN.

In addition to its work as LA, the Ministry of Agriculture also conducts the FADN survey in the field, i.e., data collection on reporting farms. The data collectors are employed in advisory service offices in the "Sector for Professional Advice in Agriculture," which operates within the "Directorate for Professional Support for the Development of Agriculture and Fisheries." In the
Croatian FADN system, the CBS is responsible for defining the FADN population according to the data from Farm Structure Survey (FSS). The reporting commercial farms (FADN sample) are a passive element of the system as they only provide the required data to the data collectors. Important for the functioning of the FADN system is also the contribution of the scientific institutions (University of Zagreb, and Josip Juraj Strossmayer University of Osijek), which have worked on the determination of the value of the standard output coefficients (SO) for individual agricultural products.

\section{Assessment of the main quality components of the FADN system}

According to the European Statistics Code of Practice (hereafter the Code), the quality of the statistical system can be assessed using 15 principles applied at three different levels: (1) institutional environment, (2) statistical processes, and (3) statistical survey results (ESS, 2017 and 2019). In this assessment, the quality of the Croatian FADN system was evaluated in accordance with selected principles and indicators from the Code. The assessment was based on available secondary sources and surveys.

\section{Professional independence}

According to the principle of Professional Independence (Principle 1 of the Code), the statistical survey sponsor should be independent of political and other influences in the process of data collection, processing and publication. The results of the interviews with staff involved at different levels and in different research processes of the FADN clearly show that there were no influences that contradict the principle of independence. However, one should keep in mind the existing organizational structure in which the entire system is under the control of the Ministry of Agriculture, except for the definition of the FADN population and the sample. This situation lends itself to phenomena and activities that could violate the said principle. Moreover, the independence of the FADN system is not guaranteed and is not explicitly regulated by a law or regulation. The Code requires periodic reporting on the status of the statistical program (indicators 1.5), which is not the case for the FADN. Moreover, the recruitment and appointment of heads of statistical programs requires transparency and professionalism (indicator 1.8), and the position of the head of the FADN in Croatia is not yet clearly defined.

\section{Mandate for data collection}

Principle 2 of the Code (Mandate for Data Collection and Access to Data) requires the existence of an appropriate mandate for statistical research, which is achieved in Croatia through two regulations: Act on Agriculture 2018 (NN 118/2018-2343) and Ordinance on the implementation of the farm accountancy data system 2015 (HR). 


\section{Commitment to quality}

Principle 4 of the Code (Commitment to Quality) identifies quality assurance as one of the prerequisites for a high-quality data collection system. In the Croatian FADN system, quality assurance is reduced to the verification of the collected data when they are entered into the electronic form of the farm report. The data are checked by built-in validation algorithms and verified by the person entering the data. There are no other procedures or internal regulations that serve to ensure quality at the national level.

\section{Statistical Confidentiality and Data Protection}

Statistical Confidentiality and Data Protection of data collected in the FADN survey (Principle 5 of the Code) are governed by national and EU regulations on the establishment and implementation of the FADN survey (Ordinance on the implementation of the farm accountancy data system $2015(H R))$. According to staff involved in the process, all those who have access to or insight into individual data from the farm report undertake in writing not to publish or disclose this data to third persons. The Department of Agricultural Information Systems of the Ministry of Agriculture believes it meets the required data security standards. Sets of individual data are stored on a computer at the Ministry of Agriculture and are only visible to individuals with super administrator status (five individuals in the ministry).

\section{Statistical methods, sampling, and definitions}

The quality of the system from the point of view of statistical methodology, procedures and ensuring accuracy and reliability of results is covered by Principles 7 , 8 and 12 of the Code (Sound Methodology, Appropriate Statistical Procedures and Accuracy and Reliability). The methodology, data definitions and basic validation rules are prescribed at the EU level. Applying these rules, the FADN system in Croatia follows the EU statistical standards and thus respects the above principles in general. As regards the definition of terms, data, and variables, these are contained in the documents "Definitions of variables used in FADN standard results" (RI / CC 1750, 2019) and "Farm Return Data Definitions" (RI/CC 1680, 2019). In Croatia, the application and verification of the consistency and accuracy of the application of all definitions relies on one person permanently employed to work on FADN. Considering the extremely large number of variables, the complexity of the calculations and the occasional change of definitions, it is necessary to increase the work force for this activity and to ensure continuous training of the staff in order to avoid errors.

The farm selection plan for the FADN sample is one of the main challenges in this area. The list of farms for surveying is not updated regularly, so farms that are no longer available for the survey appear on it. The data collectors then search for a replacement holding in their area themselves, taking into account the type and economic size and according to information provided by the Paying Agency for Agriculture, Fisheries and Rural Development (PAAFRD). Approval for the holding to be included in the sample is given by the data collection coordinator.

\section{Dissemination and availability of results}

Visibility and usability as components of the quality of statistical survey results are covered by Principle 15 (Accessibility and Clarity) of the Code. The results of the FADN survey in Croatia are publicly available on the Internet through two links. One link leads to the website of the national FADN system: http://www.fadn. $\mathrm{hr} /$, the other to the website of the FADN system at EU level: https://ec.europa.eu/agriculture/rica/. The data are presented together in the form of so-called "standard results" (weighted averages for selected groups of farms, at different regional levels-national, regional, EU), but it should be noted that the data from the two links for Croatia differ. This is due to the use of different versions of datasets. For the Croatian website, the results in HRK are published by the National Office for the FADN, and the results on the website are published by the FADN office at EC in euro.

\section{Burden on the farms surveyed}

Principle 9 of the Code (Non-excessive Burden on Respondents) addresses the issue of statistical burden on the reporting unit. The aim is to allow the necessary data to be obtained with a minimum burden on the respondents. To reduce the burden on the reporting units (or data providers, i.e., farms), in many countries existing data from other sources are used for the FADN. In Croatia, the possibility to use other sources is limited due to weak operability of the data bases. In addition, most farms are not required to keep double-entry bookkeeping and do not have detailed accounting data. Therefore, data are mostly collected using the electronic form survey technique and to a small extent from other sources. A positive step was the cooperation between the FADN department and the PAAFRD. This allowed, among other things, the retrieval of data on the public support paid by PAAFRD to farms in the FADN sample. In Croatia, only the data required for the standard farm report are collected in the FADN survey. This means that no additional effort is required from farms. While this reduces the burden on data providers, it does not follow the trend of other countries where additional sociological and environmental data are increasingly collected.

\section{Resources, costs, and benefits}

The adequacy of resources for conducting statistical surveys is covered by Principle 3 (Adequacy of Resources) of the Code. The functioning of the FADN system in Croatia relies on the human and material resources of the Ministry of Agriculture and on financial resources from the European Union. According to the data on the execution of the 2018 state budget, an expenditure of HRK 1.49 million was recorded in Croatia under the item "FADN system". This corresponds to 
about HRK 1,250 (cca EUR 167) per farm in the sample. However, this amount does not include the labour costs (salaries) of the Ministry staff carrying out the surveys. According to available estimates, the total cost per farm report could be around EUR 306 (Bradley \& Hill, 2015). The costs of the FADN system in Croatia are relatively low compared to most other EU members, but the fact is that the benefits are relatively low as well. Looking at the issue of costs and benefits of the FADN system, it can be said that the only purpose of FADN research in Croatia is to fulfill one of the conditions for EU membership. Other benefits offered by the system and related to its purpose as defined in the relevant regulations are not yet used. We stress that these other benefits are achievable in budget terms because they do not require significant additional resources. However, they do require the perception of the system as a source of data that can be used for situation analysis, impact assessment and agricultural policy planning. It also requires equipping people with the knowledge and skills to process and analyze FADN data. Staff performing duties related to the obligations of the Ministry of Agriculture as LA confirms that very little use is made of FADN survey data and results. The ministry does not seek, or conduct analyzes based on these data as a regular activity. Occasionally, certain administrations or departments request certain types of data from the FADN database but targeted analyzes are not required. As for users outside the Ministry of Agriculture, there have been several requests for individual data for scientific research purposes over the seven years. There were also several data requests from professional associations, consulting firms and the World Bank, whose experts were working on a strategic plan for the development of Croatian agriculture. Data are provided upon a written request and there is no practice of seeking feedback on the results of data use.

\section{Results of a survey among FADN data collectors}

The surveyed data collectors have been participating in the FADN survey for an average of 8 years, from which it can be concluded that they have the necessary knowledge and experience to collect data. Most of them work as agricultural extension agents and have a university degree in agriculture. A collector covers an average of 23 farms and visits each farm three times a year. The time spent per farm ranges from 10.82 to 22.22 hours (average 14.5 hours), which includes field and office work. Multiplying the average number of farms per collector by the average time spent, we can estimate that the collector spends an average of 334.42 hours of work on the FADN survey. Since their work on the FADN survey is a smaller proportion of their total work time, $40 \%$ of them do not perceive themselves as part of the FADN system. Such a perception could lead to a weaker commitment to data collection as one of the main research activities. Communication within the FADN system is generally rated as very good to excellent by data collectors on a scale of 1 (very poor) to 5 (excellent). Data collectors give higher marks to communication with direct supervisors and farms (mean scores of 4.87 and 4.15 , respectively) than to communication with other parts of the system (3.96). The majority of surveyed data collectors $(94 \%)$ indicated that there is no formal system through which they can suggest improvements in the system, but that they can and do so informally on occasion.

It is a disturbing finding that according to the collectors, about $80 \%$ of the farmers are not at all interested in the FADN survey even though they participate in it. The collectors feel that something needs to be done to change the attitude of farmers with additional motivation (e.g., rewards in the form of money, extra points in CAP support schemes, etc.). In addition, they suggest promoting FADN systems and results through farmer associations. Regarding the interest in and use of FADN research results, about $63 \%$ of the respondents visit the Croatian FADN website and rate it on average 4 out of a maximum of 5 points. There are some features that should be improved, and the improvement of the website should be accompanied by the training of collectors on how to interpret the results so that they can further disseminate the acquired knowledge in their extension work. More than $1 / 3$ of the surveyed collectors $(37 \%)$ already use the FADN data for their work. Primarily they use the data to calculate the economic size of a farm, sometimes also to analyse the situation and changes in a particular farm. Most collectors rate the usefulness of the FADN system with a score of 3.48 (median 3.00, maximum 5), which shows that even the participants of the system are not convinced of its usefulness. Collectors generally believe that data from the FADN system are primarily useful to the Ministry of Agriculture and EC, i.e., for agricultural policy making and monitoring. A small proportion of respondents are familiar with the potentials of using the FADN data for on-farm management. This response also indicates the need for additional training of collectors and development of empirical tools (models) that could increase the usefulness of the system. According to surveyed data collectors, the current situation is on the verge of sustainability for individuals in terms of workload. A particular problem is the unequal workload during the year and the situation when the FADN survey coincides with other, administrative tasks that have to be done (e.g., processing of applications for agricultural support).

\section{Results of the interviews with other participants in the implementation of the FADN survey}

As mentioned above, the collection and work with data within the FADN system is carried out by staff from two directorates of the Ministry of Agriculture: Directorate for Agricultural Policy, EU and International Cooperation, and the Directorate for Professional Support on Agriculture and Fisheries Development. The FADN office is located in the former directorate and has one person working full time for the FADN and two people performing these tasks on an occasional basis. This 
office performs key tasks for LA that include planning and organizing the FADN survey, methodological preparation, checking the collected data for completeness and accuracy, monitoring, and applying FADN regulations, communicating within the FADN team and communication with the EC RICA office, and communication with FADN data requesters. Achieving representativeness of the farm sample is a major challenge, as farmers' interest in participating is low and it is particularly difficult to get larger producers to participate.

This group of respondents see another challenge in improving the existing ways of publishing the results and making them more attractive and intuitive to the public. Staff from the Directorate of Professional Support for Agriculture and Fisheries Development are part-time participants in the FADN survey. They are involved in the FADN as data collectors (64 people) and one person is a data collection coordinator. The data collectors devote in average $16 \%$ of their annual working time to the FADN, while the coordinator devotes $50 \%$.

An interview with the staff of the General Secretariat of the Ministry of Agriculture pointed out one of the main weaknesses of the FADN system in Croatia: The FADN system is not yet recognized as a useful source of information at the level of administrative bodies. The management of the Ministry is aware of the fact that there is a FADN system, but there is not enough information about its structure, results and possibilities to use these results. It is clear that work needs to be done on the visibility of the FADN system within the Ministry of Agriculture and then beyond. CBS staff are familiar with the basic purpose and components of the FADN system, but they do not know the details of the Farm Return (i.e. FADN survey form) and data collection process. Therefore, there is a need to increase collaboration in terms of sharing FADN results and/or data collected, as CBS staff do not have enough knowledge about these results. Nine out of 15 members responded to the online survey for National FADN Committee (NFC) members. Most NFC members have more than five years of membership experience (5 members), and only two members have less than 3 years of experience. According to the responses received, NFC meetings are held up to three times a year, although the annual schedule is not always known in advance. The main topics discussed at the meetings are discussing and agreeing on the selection plan and the report on the results of the FADN survey. Occasionally, the possibilities of using the results of the FADN survey, the organization of the data collection and other topics related to the FADN are also discussed. The NFC occasionally mediates between the national FADN system and the EC, when the EC had specific needs or questions. In five of the nine cases, NFC members responded that they consult and use the FADN results in their work. NFC members find the FADN most useful to the EC, then to the Ministry of Agriculture, and least useful to other potential beneficiaries.

\section{CONCLUSION}

In this paper we present the results of the first evaluation of the national FADN research implementation system in the first seven years of its operation (2013-2019). The results indicate that the system operates in accordance with the relevant EU legislation and manages to submit the data from the annual surveys to the FADN network within the prescribed deadlines and qualitative and quantitative requirements. Until the reform of public administration in 2019, the Agricultural Extension Service of the Republic of Croatia was the FADN Liasion Agency (LA). With the implementation of the reform, extension became a part of the Ministry of Agriculture, which has assumed the role of LA. Consequently, the staff of the Ministry of Agriculture carries out all research or survey activities of the FADN, from planning to dissemination of results.

Based on the survey results, it can be concluded that currently the data collected by the FADN survey serve only one purpose: they are sent to the EU FADN network. Although both, top and middle ministry management is aware of the existence and mission of the FADN, the data are very rarely used, both within and as well as outside the Ministry.

The main challenges for the FADN system in Croatia include the following:

(1) Raising the quality level of FADN research according to the criteria of European Statistical System with respect to the quality of system and its results; (2) Ensuring an up-to-date selection plan and attracting, especially large agricultural holdings to participate in the FADN survey; (3) Increasing the motivation of data collectors and farms to work and participate in the FADN survey; (4) Reducing the burden on data collectors and on farms; (5) Ensure that the official definitions of data and variables from the standard Farm Return are applied correctly even if it is extended; (6) Increasing benefits, i.e., expanding the application of collected data and (7) Transformation of the FADN system to the Farm Sustainability Data Network (FSDN) system.

Given the established state of the organization and functioning, in response to the above challenges, we propose to focus efforts and resources on the following processes ranked by priority:

(1) Strengthen institutional capacity to achieve higher quality performance, taking into account present situation and the future needs; (2) Design and implement a comprehensive quality assurance system in the conduct of FADN research and work with data; (3) Promote the FADN system as a source of data for research and analysis among the research and professional communities, farmers, and government and public administrators; (4) Continued training of FADN staff in the application and interpretation of FADN system regulations and (5) Establishment of appropriate awards and/or recognition system for FADN survey participants, focusing on data collectors and farms. 
In the first of the processes listed, it is necessary to build capacity in terms of numbers, skills, and organization of the workforce, taking into account current needs and developments towards FSDN. This primarily means engaging additional manpower in critical positions (e.g., management, application, and control of statistical procedures) and improving the knowledge of data collectors in interpreting and using the results of the FADN.

The findings from this work can serve in planning and implementing the adaptation of the national FADN to new requirements. In addition, they provide a good starting point for work to improve the functioning of the system and for a detailed analysis of the quality of research outputs, which is outside the scope of this evaluation and which we consider necessary.

\section{ACKNOWLEDGEMENT}

This paper is a result of work on the study 'Professional service for evaluation and self-evaluation of the FADN system', which was financed by the Ministry of Agriculture of the Republic of Croatia.

\section{REFERENCES}

1. Agricultural Extension Service of the Republic of Croatia (2013). Manual for the implementation of FADN research 2013. Zagreb, Croatia

2. Bradley, D., Hill, B. (2015). Cost of and good practices for FADN data collection. Report for the European Commission by Agra CEAS Consulting. The European Commission: Brussels. https://ec.europa.eu/agriculture/ external-studies/cost-good-practices-fadn_en.

3. Council Regulation (EC) No 1217/2009 of 30 November 2009 setting up a network for the collection of accountancy data on the incomes and business operation of agricultural holdings in the European Community. http://data.europa.eu/eli/reg/2009/1217/oj.

4. Council Regulation (EC) No 1217/2009 setting up a network for the collection of accountancy data on the incomes and business operation of agricultural holdings in the European Community. https://eur-lex.europa.eu/ legal-content/EN/TXT/PDF/?uri=CELEX:32009R1217\&fr om $=$ de

5. Diazabakana, A., Latruffe, L., Bockstaller, C., Desjeux, Y., Finn, J., Kelly, E., Ryan, M., Uthes, S. (2014). A Review of Farm Level Indicators of Sustainability with a Focus on CAP and FADN. Deliverable 1.2 of the EU FP7 project FLINT. https://www.researchgate.net/ publication/312655652 Measurement of sustainability_in_agriculture_a_review_of_indicators.
6. European Commission (EC) (2009). Typology Handbook. https://fadn.pl/wp-content/uploads/2012/12/ricc1500 typology_handbook_rev3_05.10.2009.pdf.

7. European Commission (EC) (2018). Farm Accounting Data Network - An A to Z of methodology. https:// ec.europa.eu/agriculture/rica/pdf/site_en.pdf.

8. European Commission (EC) (2020). Farm to Fork Strategy. https://ec.europa.eu/food/sites/food/files/safety/docs/f2f_action-plan_2020_strategy-info_en.pdf.

9. European statistical system (ESS) (2017). Kodeks prakse europske statistike. Europska unija. https://www.dzs.hr/ Hrv/international/code_of_practice_hr.pdf.

10. European statistical system (ESS) (2019). Quality Assurance Framework of the Euro pean Statistical System ver. 2.0. Europska unija. https://ec.europa. eu/eurostat/documents/64157/4392716/ESS-OAF-V2.0final.pdf.

11. Hill, B., Bradley, D. (2016). Comparative analysis of the FADN Data Collection Systems in EU-28, 90th Annual Conference, April 4-6, 2016, Warwick University, Coventry, UK 236324, Agricultural Economics Society. https://ageconsearch.umn.edu/record/236324

12. Hill, B., Bradley, D., Vrolijk, H. (2016). Uses and Benefits of FADN Information in the EU-28. EuroChoices 15(3). https://10.1111/1746-692X.12138

13. Kožar, M. (2016). Analiza kakovosti rezultatov FADN za Slovenijo. Ljubljana, Kmetijski inštitut Slovenije. https:// www.kis.si/f/docs/Predstavitev_OEK/Analiza_kakovosti_rezultatov_FADN_za_Slovenijo.pdf.

14. Longhitano, D., Bodini, A., Povellato, A., Scardera A. (2011). Use of FADN data for appraising sustainability of Italian farms, strengths and weaknesses of the current database. Pacioli 19. The role of FADN after the CAP reform. pp. 125-134. https://edepot.wur.nl/206741.

15. NN 118/2018-2343 Zakon o poljoprivredi https://narodnenovine.nn.hr/clanci/sluzbeni/2018_12_118_2343.html

16. Ordinance on the implementation of the farm accountancy data system 2015 (HR) https://narodne-novine. nn.hr/clanci/sluzbeni/2018_01_6_170.html.

17. Vrolijk, H., Poppe, K. (2019). Costs and benefits of collecting farm data for the new CAP's data needs: empirical evidence. 172nd EAAE Seminar Agricultural policy for the environment or environmental policy for agriculture?. May 28-29, Brussels. https://library.wur.nl/ WebQuery/wurpubs/fulltext/500023.

18. Vrolijk, H., Poppe, K., Keszthelyi, S. (2016). Collecting sustainability data in different organisational settings of the European Farm Accountancy Data Network. Studies in Agricultural Economics, 118(3). pp. 138-144. http://dx.doi.org/10.7896/j.1626 


\section{PROCJENA SUSTAVA POLJOPRIVREDNIH KNJIGOVODSTVENIH PODATAKA (FADN) U HRVATSKOJ}

\section{SAŽETAK}

Hrvatska je najmlađa članica europske Mreže računovodstvenih podataka o poljoprivredi (FADN). Ovo je prvo istraživanje kojim se ocjenjuje ustroj i funkcioniranje nacionalnoga FADN sustava, temeljeno na intervjuima i anketama s uključenim osobljem i na analizi dokumentacije. Tri ključna elementa FADN sustava su Nacionalni odbor za FADN, Ministarstvo poljoprivrede kao Agencija za vezu (LA) i Hrvatski zavod za statistiku. Sve aktivnosti FADN istraživanja provodi LA, a glavni je teret prikupljanja podataka na prikupljačima podataka $i$ gospodarstvima. Sustav djeluje u skladu s nadležnim zakonodavstvom EU_a i njegov je glavni cilj ispunjavanje obveza prema mreži FADN. Podatci koje ovaj sustav prikuplja i objavljuje još se gotovo i ne koriste u druge svrhe. Ostale koristi, poput analize mjera ZPP-a i tako dalje, još nisu iskorištene. Glavni izazovi za jačanje i povećanje koristi od FADN-a su razvoj sustava osiguranja kvalitete, motiviranje skupljača $i$ farmi za sudjelovanje, promocija $i$ širenje uporabe podataka te prilagodba očekivanoj transformaciji FADN-a u mrežu podataka o održivosti gospodarstava. Glavni preduvjeti za uspješno suočavanje sustava s uočenim izazovima su jačanje kapaciteta za prikupljanje $i$ analizu podataka te djelotvoran sustav osiguranja kvalitete u FADN istraživanju.

KIjučne riječi: FADN, FSDN, Hrvatska, procjena kvalitete, računovodstvo poljoprivrednih gospodarstava

(Received on March 29, 2021; accepted on May 21, 2021 - Primljeno 29. ožujka 2021.; prihvaćeno 21. svibnja 2021.) 